worlds which children and adults occupy. Even the Plowden Committee is pleased with the way in which the earlier acquisition of reading skills in British primary schools has made it possible for young children to participate at an early age in the adult practice of leisured reading. Many of the new mathomatics programmes for young children have been consciously designed to give them a more mature appreciation of difficult matters without violating the well intentioned informality of the primary school. It is a great pity that the Plowden Committee has not followed its admirable definition of social goals by a more thorough search for intellectual goals as well. The progressive style of primary education for which John Dewey acted as an inspired impresario is better than what went before, but its practitioners are uncommonly smug in their conviction that knowing how to teach is more important than knowing what.

\section{DOOMSDAY 1967}

THE British Broadcasting Corporation has an enviable reputation for the sober and honest treatment of scientific subjects on television, so that there was some surprise last week that the corporation should have welcomed the New Year with a programme called "Challenge" designed as if to draw attention to the catastrophe there will be if something is not done to call a halt to the spread of science and technology. With perverse thoroughness, the programme vividly delineated the problems occasioned by the introduction of new techniques of all kinds. Air pollution and water pollution were fully dealt with, as was fall-out. The emergence of strains of bacteria resistant to antibiotics was held up as a danger. The toll of human life on modern highway systems was well covered, as were several of the consequences of the rapidly growing population of the world. Tales were told of how it might one day be possible to use molecular biology for doing strange things with "the nature of life itself", and there was the worry about who should be given kidney machines and who should be left without. Altogether it was a performance to keep people awake at nights. It is no wonder that one of the participants reports a young married couple of his acquaintance to have resolved not to have children of their own. Unfortunately there is no reason to suspect that the programme was intended as a subtle means of solving what is called the population problem, so that its producers are not entitled to much credit on that account.

Indeed, they are entitled to no credit at all, for they seem to have fallen into the old doomsday fallacy which has been claiming social commentators as victims at least since the invention of gunpowder. It is easy and it is also tempting to let the mind dwell on the problems which change occasions. No doubt there were even Palaeolithic Cassandras who complained that some essential quality of primitive life would be lost if people settled down to keeping domestic animals and growing crops (and there may be people now who say those ancient forebodings were correct). As things are now, with innovations of all kinds following each other in quick succession, the opportunities for gloomy prediction have multiplied enormously. But so, too, have the opportunities for avoiding disaster. Certainly it is wrong to make a fuss about the potential hazards of resistant micro-organisms without balancing this with an appreciation of the diminishing hazards of infectious diseases. It is equally misguided to forget that pollution in rivers may frequently be caused by the fertilizer plants upon which, in part, the survival of badly nourished people may depend. And wild talk about the potential hazards to society which may spring from recent work in biology is often simply wicked. The real problem is to find some way of balancing the benefits of change against the nuisances which change may often bring, or to find some way of eliminating the nuisances. The doomsday view does not help but, rather, hinders. It is no accident that petrified is often used as a synonym for frightened.

\section{FORWARD PLANNING}

The National Research Council in Canada has broken new and even unfamiliar ground in the planning of research by producing detailed forward forecasts of the resources of various kinds-people as well as money - that would be employed on university research for a decade or more ahead. First attempts in this direction were made in 1963 and, encouraged by the reception of its first forecasts, the National Research Council embarked on a more elaborate survey to use as the basis of a forward prediction, eventually published towards the end of 1966 (Expenditures on Research in Science and Engineering at Canadian Universities, NRC 9196, Ottawa, $\$ 1.00)$. At this stage the greatest interest of the exercise will be the fact that the Forecasting Committce should have embarked on it at all. Nobody will seek to hold it too rigorously to the forccasts which have actually been made, particularly at the end of a decade in which there has been a four-fold increase in the enrolment of students at Canadian universities (where there are now more than 200,000 students), and when graduate enrolment is apparently increasing at something like 20 per cent a year. Yet the actual forecasts have a conservative flavour, perhaps because they have been compiled from the individual forccasts of universities which are accustomed, in the nature of things, to suspect that rapid change cannot continue indefinitely. Even so, total expenditure on university research in Canada may increase five-fold by 1975 , from more than $\$ 60$ million a year to $\$ 322$ million a decade hence. Most of this growth is attributed to increases in the numbers of people engaged on research, both faculty members and students. The increasing cost of kecping one man fully occupied on research seems to be less worrying in Canada than it is elsewhere. It will be interesting to see how this balance shifts with time. 